\title{
POLA TABUHAN MUSIK GAMBANG KROMONG BAGI MAHASISWA JURUSAN ETNOMUSIKOLOGI ISI YOGYAKARTA
}

\author{
Sukotjo \\ Staf Pengajar Jurusan Etnomusikologi FSP ISI Yogyakarta
}

\begin{abstract}
Gambang Kromong music given in the learning process in the Department of Ethnomusicology, FSP ISI Yogyakarta has not been fully understood by its students. For this reason it is necessary to make a method of learning music Gambang Kromong which can be used by students effectively and efficiently. In the research conducted at this time about the method of learning Gambang Kromong Music is expected to facilitate students in playing the music.

The method used in conducting research is to use observation, design, formation, and socialization. The four bases in this design are expected to provide a touch of technology, knowledge, and art in developing scholarship in the field of music learning from Gambang Kromong. The preparation of the notation system will use number notation based on the solution.
\end{abstract}

Keywords: Pattern play, Gambang Kromong Music, Students

\begin{abstract}
Abstrak
Musik Gambang Kromong yang diberikan dalam proses pembelajaran di jurusan Etnomusikologi FSP ISI Yogyakarta belum sepenuhnya secara maksimal dipahami oleh para mahasiswanya. Untuk itulah perlu dibuat suatu metode pembelajaran musik Gambang Kromong yang dapat dipergunakan oleh mahasiswa secara efektif dan efisien. Dalam penelitian yang dilakukan pada saat ini tentang metode pembelajaran Musik Gambang Kromong diharapkan dapat memudah kan mahasiswa dalam memainkan musik tersebut.

Metode yang dilakukan dalam pelaksanaan penelitian yaitu dengan mempergunakan observasi, perancangan, pembentukan, dan sosialisasi. Keempat dasar dalam perancangan ini diharapkan dapat memberikan sentuhan teknologi, pengetahuan, dan seni dalam mengembangkan keilmuwan pada bidang pembelajaran musik Gambang Kromong. Penyusunan system penotasian akan mempergunakan notasi angka yang berdasarkan dari solmisasinya.
\end{abstract}

Kata Kunci: Pola Tabuhan, Musik Gambang Kromong, Mahasiswa 
Jurnal Etnomusikologi

\section{Pendahuluan}

Musik Gambang Kromong sudah dikenal pada tahun 1880 pada waktu Bek Teng Tjoe menyajikan musik tersebut untuk sebuah sajian penyambutan para tamunya. Ensambel musik ini berkembang di kalangan masyarakat Cina Benteng. Hal itu dikarenakan masyarakat tersebut dalam hal kehidupannya (segi materi) dapat terpenuhi, sehingga untuk mengadakan perjamuan tamu kerap kali mengadakan suatu sajian musik Gambang Kromong (Poa Kian Sioe, 1949: 39). Masyarakat Betawi mempergunakan musik Gambang Kromong sebagai sebuah sajian untuk hiburan dan penyemarak upacara ritual.

Musik Gambang Kromong yang berada dalam masyarakat Betawi merupakan perpaduan antara beberapa kebudayaan yang saling mengadakan interaksi (akulturasi). Hal ini dapat terlihat dari beberapa instrumen yang digunakan dalam ensambel tersebut, misalnya: instrumen gesek dan tiup dari Cina, instrumen gendang dari Sunda, dan instrumen gambang, kromong, kempul, kecrek, serta gong dari Jawa. Warna musik yang ditampilkan merupakan hasil asimilasi dari tangga nada pentatonis dan diatonis. Musik ini dalam meregenerasikan untuk para penerusnya dengan cara transmisi dari para senior kepada para juniornya, hal itu dikarenakan musik ini tergolong jenis musik yang non literate (tidak mempunyai sistem penotasian). Musik Gambang Kromong dapat dipadukan dengan sebuah jenis teater Betawi yaitu Lenong. Peran ensambel musik tersebut dalam penyajian Lenong berguna sebagai pengisi suasana dan pengiring untuk penyajiannya.

Ensambel Gambang Kromong merupakan musik tradisional yang non literate (tidak memiliki sistem penotasian). Musik ini mempergunakan tangga nada pentatonis (lima nada) sebagai nada pokok yang dipergunakan dalam pola permainan musiknya. Alat musik yang menjadi tolok ukur dari nada pokok (dasar) yang dipergunakan terdapat pada instrumen Gambang dan Kromong. Adapun urutan tangga nada tersebut apabila diukur dengan auto chromatic chord, maka dapat didekatkan dengan penggunaan notasi diatonis (solmisasi) yaitu C (do), D (re), E (mi), G (sol), dan A (la). Lima nada pokok yang dipergunakan dalam ensambel Gambang Kromong menjadikan musik tersebut mempunyai ciri khas dari segi permainannya. Harmonisasi yang terjadi dalam jalinan nadanya dapat memberikan warna suara khas dari musik Gambang Kromong. 
Jurnal Etnomusikologi

Di Jurusan Etnomusikologi FSP ISI Yogyakarta, musik Gambang Kromong diberikan kepada mahasiswanya dengan bobot 2 SKS. Mahasiswa masih mempunyai kesukaran dalam mempelajari ensambel ini karena musik Gambang Kromong termasuk musik non literate (tidak memiliki system notasi). Kesukaran yang dialami oleh mahasiswa terutama pada pola tabuhan yang dimainkan pada setiap instrumennya. Hal itu mempengaruhi dari nuansa musik Gambang Kromong yang dimainkan.

Pola pembelajaran saat ini dirasakan belum maksimal dilaksanakan karena beberapa mahasiswa masih banyak yang belum dapat memahami dalam menabuhnya secara utuh dan benar. Melihat fenomena tersebut, maka melalui penelitian tentang metode pembelajaran musik Gambang Kromong, permasalahan tersebut dapat teratasi sehingga mahasiswa dapat secara efektif dan efisien memahami dan menabuh secara utuh dan benar dalam praktek musik tersebut.

\section{Musik Gambang Kromong}

Musik gambang kromong mempunyai karakter dalam sajiannya. Sebagai suatu genre musik yang memiliki ciri khas tersebut, maka musik itu mempunyai konsep musik yang jelas. Hal itu dipertegas dengan konsep musik yang dianggap penting oleh Merriam yaitu konsep dalam hal praktek dan pertunjukan musik itu serta produksi dari suara musik, yang dikatakannya: "one of the most important of such concet is the distinction, implied or real, made between music on the one hand, and noise, or non-music, on the other; this his the basic to understanding of music in any society" (Merriam, 1964: 63)/ Salah satu hal yang paling penting dari berbagai konsep dalam musik adalah pembedaannya, tersirat atau nyata, antara musik disatu sisi, dan kebisingan atau non musik disisi lain, inilah dasar untuk memahami musik dalam setiap masyarakat.

Musik Gambang Kromong asli yang menggunakan instrumen tradisional, seperti sukong, tehyan, kongahyan, basing, jutao, gambang, kromong, gendang kempul, ningnong, dan gong, sudah mengkristal dalam kehidupan masyarakat Betawi. Perkembangan zaman melahirkan ensambel baru yang bernama musik Gambang Kromong kombinasi dengan penambahan instrumen musik Barat. Hal itu dilakukan untuk memenuhi tuntutan masyarakat pendukung yang menginginkan lagu-lagu yang populer dalam masyarakat yang dimainkan dalam oleh ensambel musik Gambang Kromong.

Selain penggunaan alat musik Barat, perbendaharaan lagu Gambang 
Jurnal Etnomusikologi

Kromong menyesuaikan dengan perkembangan lagu populer di masyarakat. Pada waktu masyarakat suka lagu Jaipongan, maka lagu-lagu Gambang Kromong didominasi lagu-lagu Jaipongan, demikian juga ketika masyarakat menggemari lagu pop, keroncong, dan dangdut. Walaupun lagu-lagu tersebut masuk dalam perbendaharaan musik Gambang Kromong, tetapi ada upaya dari para pemain musiknya untuk tetap membawakan lagu dalem, seperti Kramat Karem, Cente Manis, Jali-jali, Sirih Kuning, Balo-balo, dan lain-lain. Masuknya lagu-lagu tersebut tidak dapat dihindari karena masyarakat pendukung musik Gambang Kromong dapat menerima dan memberikan jalan bagi masuknya lagu-lagu tersebut.

Ensambel Gambang Kromong merupakan musik tradisional yang non literate (tidak memiliki sistem penotasian). Musik ini mempergunakan tangga nada pentatonis (lima nada) sebagai nada pokok yang dipergunakan dalam pola permainan musiknya. Alat musik yang menjadi tolok ukur dari nada pokok (dasar) yang dipergunakan terdapat pada instrumen Gambang dan Kromong. Adapun urutan tangga nada tersebut apabila diukur dengan auto chromatic chord, maka dapat didekatkan dengan penggunaan notasi diatonis (solmisasi) yaitu $\mathrm{C}$ (do), D (re), E (mi), G (sol), dan A (la).

Masuknya alat musik Barat dalam ensambel Gambang Kromong membuat musik tersebut harus menyesuaikan dengan penggunaan tangga nada diatonis (tujuh nada) pada pola permainannya. Adapun urutan nada pokok diatonis yang dipergunakan dalam pola permainan tersebut adalah $\mathrm{C}$ (do), D (re), E (mi), F (fa), G (sol), A (la), dan B (si).

Tangga nada diatonis yang dipergunakan dalam pola permainan musik tersebut membuat bergesernya aturanaturan yang menjadi suatu patokan (patron) dalam pola permainannya. Instrumen Gambang dan Tehyan yang menjadi alat musik pembuka (introduksi) pada setiap sajian musik Gambang Kromong kedudukannya tergeser dengan penggunaan alat musik Barat ke dalam ensambel tersebut. Gitar elektrik dan Saxopone yang merupakan instrumen Barat, lebih mendominir dalam sajian yang dimainkan.

Perubahan dalam penggunaan tangga nadanya dari lima nada (pentatonis) menjadi tujuh nada (diatonis) membuat suatu pemaksaan dalam pengungkapan emosional lagu-lagu yang dibawakan. Tangga nada diatonis yang sudah mempunyai patokan (patron) yang jelas dalam pola permainannya memberikan 
Jurnal Etnomusikologi

karakter musik Gambang Kromong menjadi berubah.

Penampilan grup musik Gambang Kromong pada masyarakat tradisi sudah memasukkan bentuk lagu keroncong, pop, dan dangdut. Lagu-lagu tradisi seperti Cente Manis, Kramat Karem, Sirih Kuning, Jali-jali, dan lain-lain, tetap masih dipergunakan, walaupun sudah berkurang dalam pembawaannya. Lagu-lagu yang dibawakan merupakan suatu kesepakatan yang sudah dijalin oleh para pemainnya.

Pola penyajian musik Gambang Kromong dalam lingkungan masyarakat Betawi sangat komunikatif. Penonton dan pemusik dapat berinteraksi secara langsung tanpa ada pembatasan. Pola interaktif keduanya memberikan kesan bahwa musik dan penonton membawa suasana menjadi semarak. Lagu-lagu yang dibawakan oleh grup Gambang Kromong yang disajikan dalam masyarakat Betawi sebagian besar lagu tradisi. Permintaan lagu dari penikmatnya banyak memesan lagu-lagu tradisi seperti Sirih Kuning, Jalijali, Cente Manis, Kramat Karem, dan lain-lain. Lagu tradisi Betawi dalam hal segi syairnya dapat digolongkan ke dalam jenis pantun yang tidak beraturan. Setiap orang penyanyi yang membawakan sebuah lagu tradisi dapat melantunkan keanekaragaman syairnya walaupun jenis lagu yang dibawakan sama judulnya.
Faktor utama yang dapat dikatakan bahwa seorang penyanyi tampak mahir apabila sudah menguasai dengan baik syair-syair lagu yang dinyanyikan. Penguasaan dengan baik dari syairnya merupakan ukuran dari kemahiran seorang penyanyi musik Gambang Kromong.

Jumlah birama yang dimainkan pada penyajian lagu tradisi Betawi disesuaikan dengan kemampuan penyanyi dalam membawakan pantun. Perubahan tempo yang terjadi dalam setiap penyajiannya menghilangkan rasa monoton pada waktu terjadi pengulangan lagu. Penyanyi membawakan pantun syair lagunya dengan mempergunakan bahasa dialek Betawi.

Tabuhan musik Gambang Kromong terbagi dalam dua golongan yaitu tabuhan ritmis dan tabuhan melodis. Alat musik tradisional yang termasuk dalam tabuhan ritmis ialah kecrek, ningnong, kempur, gendang, kempul, dan gong, sedangkan yang termasuk dalam tabuhan melodis ialah gambang, kromong, kongahyan, tehyan, sukong, jutao, dan basing (suling). Transformasi yang terjadi dalam penggunaan alat musik Barat membuat perubahan pola tabuhan yang dipergunakan pada penyajiannya. Masuknya alat-alat musik Barat dalam penyajian musik Gambang Kromong mempengaruhi pola tabuhan yang 
Jurnal Etnomusikologi

dimainkan. Instrumen musik gambang, kromong, dan tehyan yang kerap kali dipergunakan untuk mengawali (introduksi) dalam sebuah lagu tergeser dengan adanya alat musik gitar dan terompet. Jarak nada yang dimainkan oleh kedua instrument musik tersebut mengarah pada tangga nada diatonis. Penyanyi yang akan melantunkan sebuah lagu harus menyesuaikan dengan tangga nada yang dimainkan alat musik itu. Adapun contoh lagu yang terdapat dalam musik Gambang Kromong yang dituliskan dengan mempergunakan notasi angka adalah sebagai berikut:

$\mathrm{D}=\mathrm{Do}, 4 / 4$

Lagu

Sirih Kuning Ciptaan: NN.

Introduksi/Pembuka:

$5 / \overline{.5} \overline{65} \overline{35} 2 / \overline{.1} 22 \overline{.5} /$
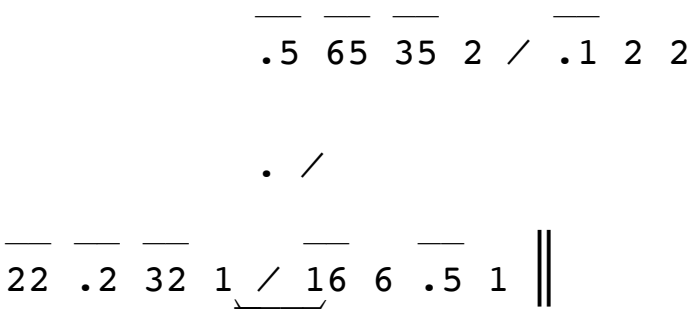

\section{Bagian A:}

535 i $/ \overline{. i} \dot{2} \dot{3} . \dot{i} / \overline{.} \dot{i} 65 /$ $\overline{.5}$ i $5 \overline{.5}$ /
Laju Laju Abang Pe- ra-hu Laju Sayang La-
Lupa Kaen Aduh Lu- pakan
Baju Sayang Ja-

$\overline{.5} \overline{65} \overline{35} 2 / \overline{.1} 22 \overline{.5} / \overline{.5} \overline{65}$

$\overline{35} 2 / \overline{.1} 22 . /$

ju-nya Sampai Sayang Lajunya Sampai Sayang

ngan Dilupa Manis Jangan Dilupa Sayang

$\dot{2} \overline{2} \overline{.2} \overline{3 \dot{2}} i, \overline{i 6} 6 \overline{.5} i$

$\mathrm{Ke} \mathrm{Su}-$ rabaya

Seni Bu- daya

\section{Bagian B:}

$\dot{3} 2$ i $6 / \overline{.6}$ i $6 . / 2$ i $65 /$

$\overline{.5}$ i $5 \overline{.5} /$

Sirih Kuning Ya Sayang Nama Lagunya Sayang Ala Sirih Kuning Ya Sayang Diatas Meja Ya Sayang

$$
\begin{gathered}
\overline{.5} \overline{65} \overline{35} 2 / \overline{.1} 22 \overline{.5} / \overline{.5} \overline{65} \\
\overline{35} 2 / \overline{.1} 22 . /
\end{gathered}
$$

Yang PutihKuning Ya Sayang Yang Putih Kuning Ya Nona Yang Bajunya Kuning Ya Sayang Yang Bajunya Kuning Ya Sayang

$$
\dot{2} \overline{2} \overline{. \dot{2}} \overline{\dot{3} \dot{2}} i \underbrace{1} \overline{i 6} 6 \overline{.5} \mathrm{i} \|
$$

\section{Siapa Namanya}

Orangnya Manja

Pembawaan lagu Sirih Kuning banyak mempergunakan gaya khas dari musik Gambang Kromong. Karakter yang menonjol dari teknik pengolahan vokalnya membuat suatu harmonisasi dengan pengiring musiknya. Syair yang 
Jurnal Etnomusikologi

dibawakan dapat diganti dengan kemampuan seorang penyanyi dalam perbendaharaan pantun yang dimilikinya. Pada setiap bagian (bagian A dan bagian B) diulang dan isian syairnya disesuaikan dengan kemampuan seorang penyanyi dalam perbendaharaan kalimat syairnya yang berbentuk pantun. Semakin banyak perbendaharaan syair yang dilakukan oleh seorang penyanyi, maka hal itu menjadikan pembawaan lagunya akan lebih dinamis. Syair-syair yang dilantunkan dapat berisi pujian atau sanjungan, kritikan, ataupun sosialita yang terdapat dalam masyarakat.

$\mathrm{D}=\mathrm{Do}, 4 / 4$

Lagu Jali-

jali

Ciptaan: NN

\section{Introduksi/Pembuka:}

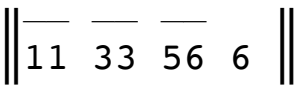

\section{Lagu Pokok:}

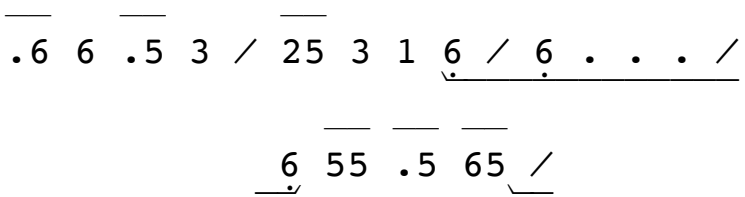

$$
\text { I- ni Di e } \begin{gathered}
\text { Si Jali- ja- li } \\
\text { Lagunya Enak }
\end{gathered}
$$

$5 \overline{.5} \overline{55} \overline{65}, \overline{.3} \overline{53} 35 / 51 \overline{11}$

$$
\overline{.5} / \overline{55} \overline{11} \overline{21} 6 \text {, }
$$

Lagunya Enak Merdu Sekali

$$
\begin{gathered}
\overline{.6} 6 \overline{.5} 3 / \overline{25} 316 / 6 . . . / \\
6 \overline{55} \overline{.5} \overline{65 /}
\end{gathered}
$$

I- ni Di e Si Jali- ja- li Lagunya Enak

$5 \overline{5} \overline{55} \overline{65}, \overline{.3} \overline{53} 3 \underbrace{5 / 5} 1 \overline{11}$

$\overline{5}, \overline{55} \overline{11} \overline{12} \underbrace{3 /}$

Lagunya Enak Merdu Sekali

$3 \overline{55} \overline{.5} \overline{\mathrm{i} 6} / 6 \overline{.5} \overline{55} \overline{\mathrm{i} 6} / \overline{.5} \overline{55}$

$\overline{.3} 5 / \overline{.3} 2 . . /$

Cape Sedikit Cape Sedikit

Gak Perduli

Sayang

$2 \overline{55.5} \overline{53 / 3} . \overline{5} \overline{53} \overline{23} / \overline{.1}$
$\overline{11} \overline{53} 1 / 11 \overline{11} \overline{.5}$

Asal kan Tuan Asal kan Tuan

Senang di Hati

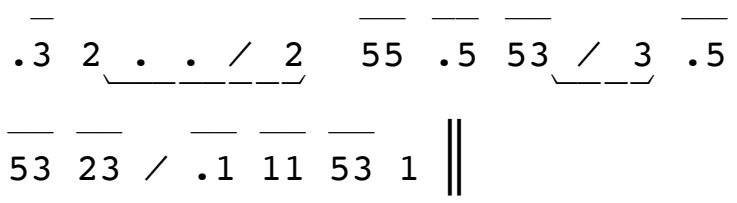

Sayang Saya Menyanyi Saya Menyanyi Menghibur hati 
Jurnal Etnomusikologi

Lagu jali-jali sudah sangat dikenal dalam sajian musik Gambang Kromong. Lagu ini menggambarkan suatu kiasan tentang kehidupan masyarakat Betawi. Dalam perkembangannya, lagu tersebut sudah semakin kurang diminati oleh masyarakat pendukungnya. Adanya lagulagu populer dalam masyarakat pendukung Gambang Kromong mengakibatkan volume penyajian lagu khas Gambang Kromong tergeser kedudukannya. Gaya (style) yang dibawakan oleh para penyanyi dengan adanya lagu-lagu populer menjadikan lebih didominasi dengan olahan vokal diatonis.

Alat musik yang dipergunakan dalam ensambel Gambang Kromong terdiri dari dua bagian yaitu yang memainkan pola ritmis dan melodis. Pola ritmis yang dimainkan oleh instrumen kecrek, gendang, ningnong, kempul dan gong memberikan aksen yang jelas dalam penegasan dan penguat irama yang dimainkan. Melodis yang dimainkan oleh instrumen sukong, tehyan, kongahyan, basing/suling, gambang, dan kromong menjadikan sebuah pola harmonis (keselarasan) diantara alat musik tersebut.

\section{Bentuk dan Motif Lagu}

Penampilan grup musik Gambang Kromong pada masyarakat tradisi sudah memasukkan bentuk lagu keroncong, pop, dan dangdut. Lagu-lagu tradisi seperti Cente Manis, Kramat Karem, Sirih Kuning, Jali-jali, dan lain-lain, tetap masih dipergunakan, walaupun sudah berkurang dalam pembawaannya. Lagulagu yang dibawakan merupakan suatu kesepakatan yang sudah dijalin oleh para pemainnya.

Pola penyajian musik Gambang Kromong dalam lingkungan masyarakat Betawi sangat komunikatif. Penonton dan pemusik dapat berinteraksi secara langsung tanpa ada pembatasan. Pola interaktif keduanya memberikan kesan bahwa musik dan penonton membawa suasana menjadi semarak.

Lagu-lagu yang dibawakan oleh grup Gambang Kromong yang disajikan dalam masyarakat Betawi sebagian besar lagu tradisi. Permintaan lagu dari penikmatnya banyak memesan lagu-lagu tradisi seperti Sirih Kuning, Jali-jali, Cente Manis, Kramat Karem, dan lainlain. Lagu tradisi Betawi dalam hal segi syairnya dapat digolongkan ke dalam jenis pantun yang tidak beraturan. Setiap orang penyanyi yang membawakan sebuah lagu tradisi dapat melantunkan keanekaragaman syairnya walaupun jenis lagu yang dibawakan sama judulnya. Faktor utama yang dapat dikatakan bahwa seorang penyanyi tampak mahir apabila sudah menguasai 
Jurnal Etnomusikologi

dengan baik syair-syair lagu yang dinyanyikan. Penguasaan dengan baik dari syairnya merupakan ukuran dari kemahiran seorang penyanyi musik Gambang Kromong.

Jumlah birama yang dimainkan pada penyajian lagu tradisi Betawi disesuaikan dengan kemampuan penyanyi dalam membawakan pantun. Perubahan tempo yang terjadi dalam setiap penyajiannya menghilangkan rasa monoton pada waktu terjadi pengulangan lagu. Penyanyi membawakan pantun syair lagunya dengan mempergunakan bahasa dialek Betawi.

Tabuhan musik Gambang Kromong terbagi dalam dua golongan yaitu tabuhan ritmis dan tabuhan melodis. Alat musik tradisional yang termasuk dalam tabuhan ritmis ialah kecrek, ningnong, kempur, gendang, kempul, dan gong, sedangkan yang termasuk dalam tabuhan melodis ialah gambang, kromong, kongahyan, tehyan, sukong, jutao, dan basing (suling). Transformasi yang terjadi dalam penggunaan alat musik Barat membuat perubahan pola tabuhan yang dipergunakan pada penyajiannya. Masuknya alat-alat musik Barat dalam penyajian musik Gambang Kromong mempengaruhi pola tabuhan yang dimainkan. Instrumen musik gambang, kromong, dan tehyan yang kerap kali dipergunakan untuk mengawali (introduksi) dalam sebuah lagu tergeser dengan adanya alat musik gitar dan terompet. Jarak nada yang dimainkan oleh kedua 132nstrument musik tersebut mengarah pada tangga nada diatonis. Penyanyi yang akan melantunkan sebuah lagu harus menyesuaikan dengan tangga nada yang dimainkan alat musik itu.

\section{Pola Tabuhan}

Musik Gambang Kromong dalam pola permainannya mengenal dua buah tempo yaitu lambat dan cepat. Tempo tersebut mempengaruhi dalam pola tabuhan dalam instrumen yang dimainkan. Adapun beberapa instrumen yang dimainkan dalam sebuah lagu adalah sebagai berikut:

\section{Pola Tabuhan Lagu Sirih Kuning}

1. Instrumen Gambang (mengikuti melodi lagu).

\section{Introduksi/Pembuka:}

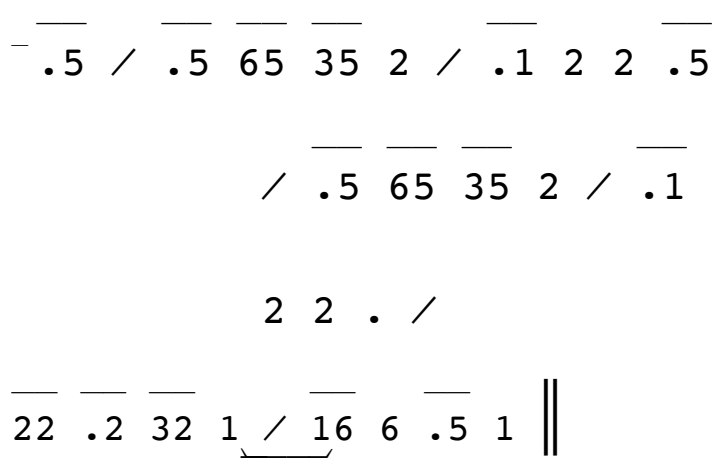


Jurnal Etnomusikologi

\section{Bagian A:}

535 i $/ \overline{. i} \dot{2} \dot{3} . \dot{i} / \overline{.}$ i $65 /$

$\overline{.5}$ i $5 \overline{.5} /$

$\overline{.5} \overline{65} \overline{35} 2 / \overline{.1} 22 \overline{.5} / \overline{.5} \overline{65}$ $\overline{35} 2, \overline{.1} 22$.

$\overline{\dot{2} \dot{2}} \overline{. \dot{2}} \overline{\dot{3} \dot{2}} \dot{i}, \overline{\mathrm{i} \sigma} 6 \overline{.5} \mathrm{i} \|$

\section{Bagian B:}

$\dot{3} 2$ i $6 / \overline{.6}$ i $6 . / 2$ i $65 /$

$\overline{.5}$ i $5 \overline{.5} /$

$\overline{.5} \overline{65} \overline{35} 2 / \overline{.1} 22 \overline{.5} / \overline{.5} \overline{65}$

$$
\overline{35} 2 / \overline{.1} 22 . /
$$

$\overline{\dot{2} \dot{2}} \overline{. \dot{2}} \overline{\dot{3} \dot{2}} \dot{i}, \overline{\mathrm{i} \sigma} 6 \overline{.5} \mathrm{i} \|$

\section{Instrumen Kromong}

\section{Introduksi/Pembuka:}

$\overline{.2} \overline{52} \overline{.2} \overline{52} \overline{.2}, \overline{52} \overline{.2} \overline{52} \overline{.2}$,

$$
\overline{52} \overline{.2} \overline{52} \overline{.1} /
$$

$\overline{35} \overline{65} \overline{32} 1 / \overline{56} 1 \overline{56} 1 \|$

\section{Bagian A:}

. . $\overline{.5} / \overline{35} \overline{.5} \overline{35} \overline{.5} / \overline{35} \overline{.5}$

$\overline{35} \overline{55} / \overline{35} \overline{.5} \overline{35} \overline{.5}$ $\overline{35} \overline{.5} \overline{35} \overline{25}, \overline{25} \overline{.5} \overline{25} \overline{25} / \overline{25}$

$\overline{.5} \overline{25} \overline{25}, \overline{52} \overline{.2} \overline{52}$

.1

$\overline{35} \overline{65} \overline{32} 1 / \overline{56} 1 \overline{56} 1 \|$

\section{Bagian B:}

. . $\overline{.6} / \overline{16} \overline{.6} \overline{16} \overline{66} / \overline{16} \overline{.6}$

$\overline{16} \overline{55}, \overline{35} \overline{.5} \overline{35} \overline{55}$

$\overline{35} \overline{.5} \overline{35} \overline{25} / \overline{25} \overline{.5} \overline{25} \overline{.5} / \overline{25}$

$.52525 / 25.52525 /$

$\overline{25} \overline{65} \overline{32} 1 / \overline{56} 1 \overline{56} 1 \|$

3. Instrumen Kecrek, Ningnong dan Kempur/Kemong (Pola ritmis)

Instrumen Kecrek dan Kemong dalam suatu lagu memainkan pola ritmis sebagai berikut:

- Instrumen Kecrek

.. $\overline{. \Delta} \| \overline{\Delta \Delta} \overline{. \Delta} \overline{\Delta \Delta} \overline{. \Delta}, \overline{\Delta \Delta}$

$\overline{\cdot \Delta} \overline{\Delta \Delta} \cdot \overline{\cdot \Delta} \|$

- Instrumen Ningnong

- $. \dot{-} \| d \overline{d d} d d / d \overline{d d} d d$

$\|$

- Instrumen Kempur/Kemong

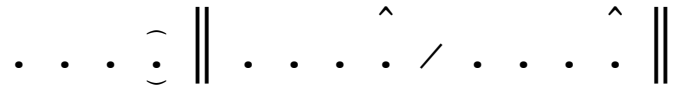

4. Instrumen Kempul dan Gong Introduksi/Pembuka: 
Jurnal Etnomusikologi

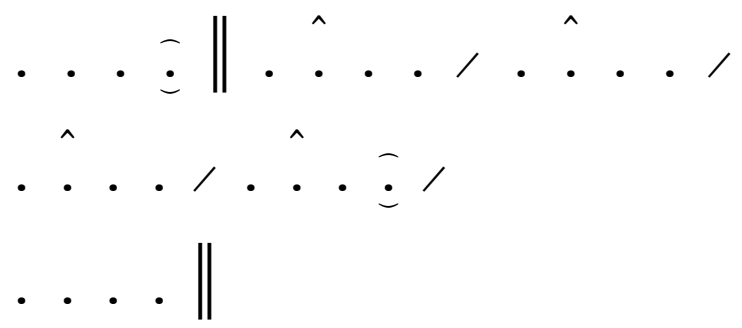

Bagian A:

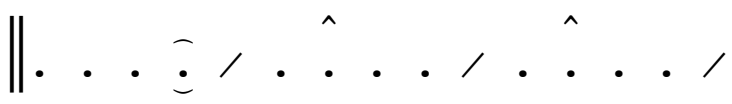

$\stackrel{\wedge}{\bullet} \cdot \dot{\iota} / \cdot \cdot \cdot \cdot \|$

\section{Bagian B:}

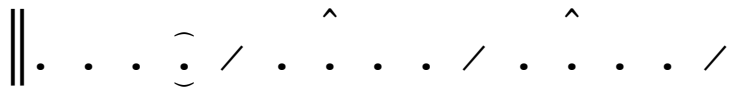

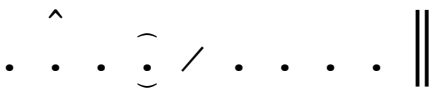

\section{Instrumen Gendang}

Tangan Kanan :

$$
\begin{aligned}
& \text { • } \overline{\text {. }} a^{*} \| \overline{a^{\prime}} a^{*} \overline{a^{\prime \prime}} a^{*} \overline{a^{\prime}} a^{*} \overline{a^{\prime \prime}} a^{*} \\
& \overline{a^{\prime}} a^{*} \overline{a^{\prime \prime}} a^{*} \overline{a^{\prime}} a^{*} \overline{a^{\prime \prime}} a^{*}
\end{aligned}
$$

Tangan Kiri:

. . u u $\overline{. u} \cdot \bar{u} \cdot \underline{u} \cdot \bar{u} / . \bar{u} u$

$\bar{u} \mathrm{u} / . \overline{\mathrm{u}} \cdot \overline{\underline{u}} . \underline{\mathrm{u}} \overline{\mathrm{u}} /$

. $\overline{u v} \bar{u} u / \bar{u} u \bar{u} u /$.

$\overline{U^{\prime} U^{\prime}} \overline{U^{\prime} U^{\prime}} \cup$

$$
\begin{aligned}
& \begin{array}{l||llll}
\text { Bagian A : } & . \mathrm{U} & \cdot & \underline{\underline{u}} . \underline{\mathrm{U}} & . \mathrm{U}
\end{array}
\end{aligned}
$$

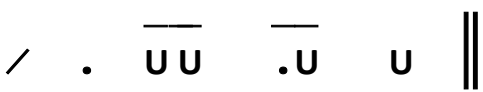
, $\overline{. u} \quad \underline{u} . u$ Peralihan : $\mid \overline{U U} \quad \underline{u} \overline{U U} \quad$, - $\overline{\underline{u}} \underline{\underline{u}} \underline{\underline{u}} \underline{u} \quad \|$

Cindek/Coda : $\| \overline{. U} \quad \underline{u} \quad \overline{\mathrm{U} U}$, $\overline{. u} \cdot \overline{\underline{u}} \underline{u}$.

Keterangan:

$\begin{array}{ll}\mathbf{U}=\text { dong } & \mathbf{a}^{*}=\text { pong } \\ \mathbf{U}=\text { tung } & \mathbf{a}^{\prime}=\text { peng } \\ \mathbf{U}^{\prime}=\text { det } & \mathbf{a}^{\prime \prime}=\text { pak }\end{array}$

6. Instrumen Tehyan dan Suling mengikuti alur melodinya.

\section{Pola Tabuhan Lagu Jali-jali}

1. Instrumen Gambang Introduksi/Pembuka:

$\|\overline{11} \overline{33} \overline{56} \overline{66}\|$

Lagu Pokok:

$\overline{36} \overline{.6} \overline{36} \overline{.6}, \overline{36} \overline{.6} \overline{36} \overline{55} / \overline{35}$

$\overline{.5} \overline{35} .5 / \overline{35} \overline{.5} \overline{35}$

$66 /$ 
Jurnal Etnomusikologi

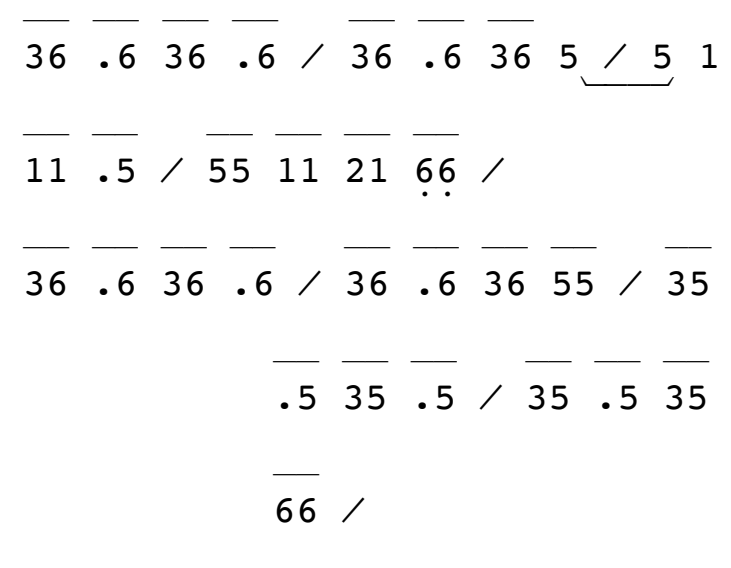

$\overline{36} \overline{.6} \overline{36} \overline{.6} / \overline{36} \overline{.6} \overline{36} 5 / 51$

$\overline{11} \overline{.5}, \overline{55} \overline{11} \overline{12} \overline{36}$

$\overline{36} \overline{.6} \overline{36} \overline{.6}, \overline{36} \overline{.6} \overline{36} \overline{.6} / \overline{36}$

$\overline{.6} \overline{36} \overline{55}, \overline{35} \overline{.5} \overline{35}$

.5

$\overline{35} \overline{.5} \overline{35} \overline{25}, \overline{25} \overline{.5} \overline{25} \overline{35}, \overline{35}$

$\overline{.5} \overline{35} 1 / 11 \overline{11} \overline{.5} / \overline{55} \overline{11} \overline{12}$

$\overline{36}, \overline{36} \overline{.6} \overline{36} \overline{.6}, \overline{36} \overline{.6} \overline{36} \overline{.6}$

$\overline{36} \overline{.6} \overline{36} \overline{55}$

$\overline{35} \overline{.5} \overline{35} \overline{.5}, \overline{35} \overline{.5} \overline{35} \overline{25}, \overline{25}$

$\overline{.5} \overline{25} \overline{35}, \overline{35} \overline{.5} \overline{35} 1 \|$

\section{Instrumen Kromong}

Introduksi/Pembuka:

$\|\overline{11} \overline{33} \overline{56} \overline{66}\|$

\section{Lagu Pokok:}

$$
\begin{aligned}
& \overline{36} \overline{.6} \overline{36} \overline{.6}, \overline{36} \overline{.6} \overline{36} \overline{55} / \overline{35} \\
& \overline{.5} \overline{35} .5 / \overline{35} \overline{.5} \overline{35} \\
& \overline{66} / \\
& \overline{36} \overline{.6} \overline{36} \overline{.6}, \overline{36} \overline{.6} \overline{36} 5 / 51 \\
& \overline{11} \overline{.5} / \overline{55} \overline{11} \overline{21} \overline{66}, \\
& \overline{36} \overline{.6} \overline{36} \overline{.6} / \overline{36} \overline{.6} \overline{36} \overline{55} / \overline{35} \\
& \overline{.5} \overline{35} .5, \overline{35} . \overline{55} \\
& \overline{66} / \\
& \overline{36} \overline{.6} \overline{36} \overline{.6}, \overline{36} \overline{.6} \overline{36} 5 / 51 \\
& \overline{11} \overline{.5} / \overline{55} \overline{11} \overline{12} \overline{36} / \\
& \overline{36} \overline{.6} \overline{36} \overline{.6}, \overline{36} \overline{.6} \overline{36} \overline{.6}, \overline{36} \\
& \overline{.6} \overline{36} \overline{55}, \overline{35} \overline{.5} \overline{35} \\
& .5 \\
& \overline{35} \overline{.5} \overline{35} \overline{25}, \overline{25} \overline{.5} \overline{25} \overline{35}, \overline{35} \\
& \overline{.5} \overline{35} 1 / 11 \overline{11} \overline{.5} / \overline{55} \overline{11} \overline{12} \\
& \overline{36}, \overline{36} \overline{.6} \overline{36} \overline{.6}, \overline{36} \overline{.6} \overline{36} \overline{.6} \\
& \overline{36} \overline{.6} \overline{36} \overline{55} \\
& \overline{35} \overline{.5} \overline{35} \overline{.5}, \overline{35} \overline{.5} \overline{35} \overline{25}, \overline{25} \\
& \overline{.5} \overline{25} \overline{35}, \overline{35} \overline{.5} \overline{35} 1
\end{aligned}
$$

3. Instrumen Kecrek, Ningnong dan Kempur/Kemong (Pola ritmis) 
Jurnal Etnomusikologi

Instrumen Kecrek dan Kemong dalam suatu lagu memainkan pola ritmis sebagai berikut:

- Instrumen Kecrek

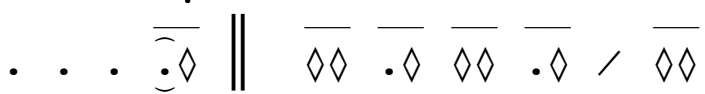

$\overline{\cdot \nabla} \overline{\Delta \Delta} \cdot \nabla \|$

- Instrumen Ningnong

. $\check{-} \| d \overline{d d} d d / d \overline{d d} d d$

$\|$

- Instrumen Kempur/Kemong

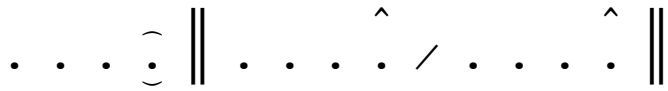

\section{Instrumen Kempul dan Gong} Introduksi/Pembuka:

$\|. . \quad \cdot \quad\|$

\section{Bagian A:}

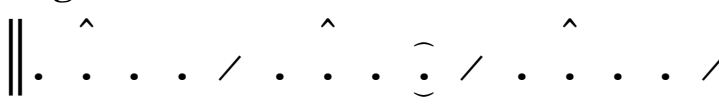

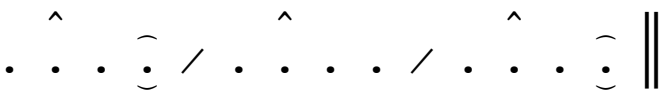

\section{Bagian B:}

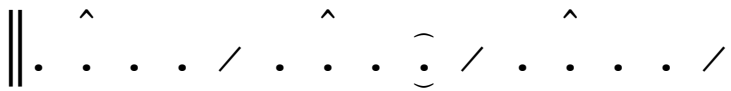

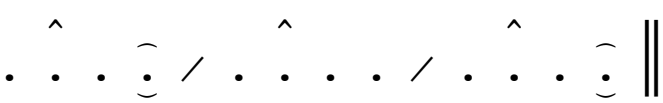

\section{Instrumen Gendang}

Tangan Kanan :

. . . $a^{*} \| \overline{a^{\prime}} a^{*} \overline{a^{\prime \prime}} a^{*} \overline{a^{\prime}} a^{*} \overline{a^{\prime \prime} a^{*}}$,

$\overline{a^{\prime}} a^{*} \overline{a^{\prime \prime}}{ }^{*} \overline{a^{\prime}} a^{*} \overline{a^{\prime \prime}}{ }^{*}$
Tangan Kiri:

. . u u $\overline{. u} \cdot \bar{u} \cdot \underline{u} \cdot \bar{u} / . \bar{u}$

$\bar{u} u / . \bar{u} \cdot \bar{u} . \underline{u} . \bar{u} /$

. $\overline{u v} \cdot \bar{u} u / \bar{u} \underline{u} \overline{u v} u /$.

$\overline{U^{\prime} U^{\prime}} \overline{U^{\prime} U^{\prime}} U$

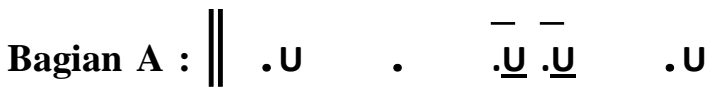

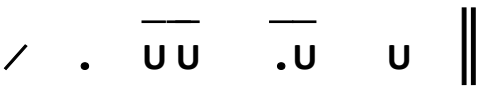

Bagian B : $\mid \overline{. U} \quad \underline{u} \quad \cdot \quad \overline{U U}$

, $\overline{\text { u }} \underline{\mathrm{u}} \cdot \mathrm{u}$

Peralihan: $\mid \overline{U U} \quad \underline{u} \bar{U} u$,

- $\overline{\underline{u}} \underline{\underline{U}} \quad \overline{\mathrm{u}} \underline{\mathrm{u}} \quad \mathrm{u}$

Cindek/Coda : $\| \overline{. U} \quad \underline{u} \quad \overline{\mathrm{U} U}$, $\overline{. U} \cdot \overline{\underline{u}} \underline{u} . \|$

Keterangan:

$\begin{array}{ll}\mathbf{U}=\text { dong } & \mathbf{a}^{*}=\text { pong } \\ \mathbf{U}=\text { tung } & \mathbf{a}^{\prime}=\text { peng } \\ \bar{U}^{\prime}=\text { det } & \mathbf{a}^{\prime \prime}=\text { pak }\end{array}$

6. Instrumen Tehyan dan Suling mengikuti alur melodinya.

\section{Penutup}

Pengenalan musik Gambang Kromong dalam masyarakat akademisi masih kurang ditanggapi dengan baik 
Jurnal Etnomusikologi

karena musiknya yang bersifat non literate dan tidak mempunyai buku panduan dalam pola tabuhannya. Perkembangan di masyarakat Betawi sendiri musik ini dalam mempelajarinya hanya melihat dari para senior yang memainkan ansambel tersebut. Musik Gambang Kromong dipelajari perguruan tinggi seperti Institut Seni Indonesia Yogyakarta dan Institut Kesenian Jakarta sebagai sebuah bentuk mata kuliah dari ensambel musik dari suatu masyarakat etnis.

Metode pengajaran yang dilakukan di Institut Seni Indonesia Yogyakarta kurang maksimal dipahami oleh mahasiswa karena musik ini tidak mempunyai sistem penotasian. Hal itu yang menyebabkan mahasiswa ada yang menafsirkannya menurut kemampuan yang dimilikinya. Hal tersebut membuat nuansa musik Gambang Kromong menjadi berubah sehingga perlu diarahkan kepada pola-pola tradisi untuk mempelajarinya secara praktis dan efisien. Beberapa modul pembelajaran dalam mempelajari musik Gambang Kromong diharapkan lebih memudahkan mahasiswa di jurusan Etnomusikologi FSP ISI Yogyakarta dalam mempelajari ensambel Gambang Kromong.

\section{DAFTAR PUSTAKA}

Andriessen, 1965, Hal Ihwal Musik, terjemahan J.A. Dungga, Pradnja Jakarta: Paramita.

Bogdan, Robert, and Steven J. Taylor, 1975. Introduction to Qualitative Research Methods,

New York: John Wiley \& Sons.

Bouman, P.J., 1980, Ilmu Masyarakat, terjemahan H.B. Jassin P.T. Jakarta: Pembangunan.

$\begin{array}{lcc}\text { Fundamental, } & \begin{array}{c}1982, \\ \text { terjemahan }\end{array} & \begin{array}{c}\text { Sosiologi } \\ \text { Ratmoko, }\end{array}\end{array}$ Bandung:Harapan offset.

Budiaman, et al., 1979, Folklor Betawi, Jakarta: Pustaka Jaya.

Kayam, Umar, 1981, Seni, Tradisi, Masyarakat, Jakarta: Sinar Harapan. Transaction Books.

Malm, William P., 1967, Music Cultures of the Pasific, the Near East, and Asia, Chicago:

North Western University Press.

Merriam, Alan P., "The Anthropology of Music", Chicago: North Western

University Press, 1964.

Muhadjir, et al., 1985, Peta Seni Budaya Betawi, Jakarta: Proyek Inventarisasi dan Dokumentasi Kebudayaan Daerah.

Netll, Bruno, 1964, Theory and Method in Ethnomusicology, New York: The Free Press of

Glencoe.

Nio Joe Lan, 1961. Peradaban Tionghoa Selayang Pandang, Djakarta: Keng Po.

Sedyawati, Edi, 1981, Pertumbuhan Seni Pertunjukan, Jakarta: Sinar Harapan. 